\title{
Dimensions of the creative industry in individual regions of the Slovak Republic
}

\author{
Slavka Šagátová ${ }^{1, *}$ \\ ${ }^{1}$ FPM EU in Bratislava, Department of Business Economy, Dolnozemská cesta1, 85235 Bratislava, \\ Slovakia
}

\begin{abstract}
The creative industries are an area of the economy that uses human creativity for their production and thus becomes an important sector in promoting the ideas of sustainable development. However, differences of opinion in the definition of the term keat industry complicate the study of its potential. The present article therefore focuses on identifying the basic areas of the creative industries and revealing their links to other elements of the economy. It also examines the representation of the creative industry in individual regions of the Slovak Republic in terms of their number and achieved revenues. The survey confirms the presence of the creative industry in all regions of the Slovak Republic. Its greatest concentration is in large cities and the most represented industry is the advertising industry.
\end{abstract}

\section{Definition of the creative industry}

The creative industry is a sector with growth potential, not only in the sector, but its activities can be a determinant of the development of other sectors of the economy of individual countries. The benefit of the creative industry is also its cross-sectoral dimension with minimal territorial constraints. [1] The volume of the creative industry in the world is constantly growing and employs more and more employees. The development of the creative industry can also make a significant contribution to globalization, as it creates a larger volume of tradable services applicable in the broader foreign market. [2] The importance of this issue is underlined by increased publishing activity in this area. Sinhof identified in his survey the keyword "creative industry" as one of the two most common in the sample of 131 scholarly articles examined. [3]

As a sector based on human creativity, the creative industry is closely linked to the cultural industry. In some publications, the combination and overlapping of these terms occur. An even more complicated fact is the phenomenon of understanding the practice of creative companies, which represent a heterodox sector with high levels of variation between companies. $[4,5]$ KEA characterizes the creative industry as an area where culture becomes a creative input in producing non-creative goods. [6] These are activities that are not necessary of an industrial nature. However, prototypes can also be products. From a legal point of view, the outputs of the creative industry may be based on copyright, while

*Corresponding author: slavka.sagatova@euba.sk 
they may include other inputs in the field of intellectual property rights (e.g., trademarks) too. The essence of the production of this industry is the use of various forms of creativity, creative skills, and creative professionals (for example, in the field of art). [6, 7] The specific types of enterprises included in the creative industry sector may differ slightly depending on the authors (experts or institutions) or the establishment time (given the current state of knowledge).

In the conditions of the Slovak Republic, the issue of the creative industry is covered by the Ministry of Culture, which perceives this branch as a part of the Cultural and Creative Industry. In order to define its content, in 2019 it adopted the ESSnet-Culture methodology, according to which the CCP was divided into three areas in accordance with the definitions of the KEA: Cultural core, Cultural industry, Creative industry. Three basic types of companies were included in the creative industry.

Table 1. Areas of creative industry according to the Ministry of Culture of the Slovak Republic

\begin{tabular}{|c|c|c|c|c|}
\hline $\begin{array}{c}\text { Sector according to } \\
\text { KEA }\end{array}$ & $\begin{array}{c}\text { Industry name } \\
\text { according to } \\
\text { ESSnet }\end{array}$ & $\begin{array}{c}\text { Proposal of the } \\
\text { Slovak name of } \\
\text { the area }\end{array}$ & $\begin{array}{c}\text { Code } \\
\text { NACE }\end{array}$ & $\begin{array}{c}\text { NACE } \\
\text { nomenclature }\end{array}$ \\
\hline Creative industry & Visual arts & Design & 7410 & $\begin{array}{c}\text { Specialized design } \\
\text { activities }\end{array}$ \\
\hline Creative industry & Architecture & Architecture & 7111 & $\begin{array}{c}\text { Architectural } \\
\text { activities }\end{array}$ \\
\hline Creative industry & Advertising & Advertising & 7311 & $\begin{array}{c}\text { Advertising } \\
\text { agencies }\end{array}$ \\
\hline
\end{tabular}

Source: Podrobná definícia odvetví kultúrneho a kreatívneho priemyslu [8]

The content of particular areas is based on the sector specification in NACE. However, specialized design activities include fashion design of personal or household goods, industrial design, activities of graphic designers and interior decorators. Architectural activities include architectural consultancy in the field of constructions as well as agglomeration and landscape. Finally, advertising agencies are perceived in the context of a whole range of advertising services, from consulting through the creation, production, and placement of advertising materials, space management up to the implementation of entire advertising campaigns.

\section{Key areas of the creative industry}

Defining individual areas of the creative industry is an essential tool for analyzing and evaluating their development and finding opportunities for their effective development. The product of subjects in the field of design is the design of an object intended for mass reproduction or consumption (cars, furniture, clothing, etc.). The design represents added value not only from an aesthetic point of view but also has an impact on the entire production process. Production in the field of design can be divided into three primary areas: industrial design, interior and architectural design, and graphic design. The industrial design focuses on specific production to design a completely new product or innovate the original product. Innovations are focused on improving appearance, performance, increasing user comfort, etc. They can also be a link between smart technologies and innovations, the development of which is linked to industry 4.0. [9] Design proposals may relate to consumer products, packaging, industrial goods, fashion brands. In the case of interior and architectural design, it is a production to improve the performance of interiors or architectural elements, whether in terms of their functionality or aesthetics. As the design industry thus identified may overlap within the creative industry with the field of architecture, only the activity of interior decorators is included in the design as an area of 
the creative industry. Graphic design focuses primarily on the production of designs such as the company or product logos, the appearance of corporate documents, promotional materials, and manuals, multimedia presentations, and websites. The impact of design on the production capabilities of businesses makes it an essential factor in competitiveness. [10] The use of the services of the design industry could help to balance the competitive forces between technology leaders and leaders (leaders and followers), the distance (increases) of which increases with the competition. [11]

Architecture creates an environment that provides space for human activities but also shapes and influences people. [12] The field of architecture consists of both independent architects and architectural firms. They provide architectural and engineering services and related technical advice. Their product can be an architectural work, delivery, and coordination of product documentation, or the processor of its parts, cooperation in the proper implementation of the project, coordination of individual actors involved in the project from its completion to implementation. The results of the architect's work in the form of building designs, public spaces, urban complexes, restoration, and works of landscape architecture have a significant impact on the health, lives, and property of citizens and the natural and cultural environment. [13] The final consumers of their activities can be private persons, companies or public institutions.

The product of advertising is an advertising work. The process of its production itself includes two aspects of production and process. Production is the embodiment of ideas, which on the one hand, are formed outside the production environment; for example, in society, in demand as an expression of the development of society, or on the other hand, represent an artificial influence on behavior. The whole process is relatively long and involves a large number of active participants and professions. According to the above facts, the subjects of advertising as a branch of the creative industry are advertising agencies and similar companies within, e.g., communication and brand building. [14] These companies sell services to other companies and organizations. At the same time, they buy services and products from other industries, including the cultural and creative industries. Consumption of production factors in the creative industry can be identified in the production process as well as distribution. In its production activities, the advertising industry consumes creative products from industries such as film, fine arts, music, etc. The distribution process involves the consumption of media space, for example, in TV, radio, periodicals. According to Stephan Loerke, CEO of WFA, advertising promotes competition and business innovation, provides information for consumers' purchasing decisions, and contributes to the financing of media services by purchasing media space. At present, online advertising plays an important role, which represents a substantial part of all advertising expenses. [15] In this context, however, it is necessary to draw attention to new paradigms in advertising. Some of the creative tasks traditionally provided by advertising agencies are now being taken over by media platforms. [16]

Creative industry business can be carried out by independent individuals (especially in the field of design and architecture) or companies providing design, architectural, and advertising services. They can provide their production to final consumers but also companies, organizations, or public institutions. Due to the creative side of this production, it has an impact not only on the direct satisfaction of a certain customer need but also influences the general public with its aesthetic value. The connection of the creative industry to the urban and regional economy is also identified through creative clusters. [17] It is also important to mention that the final impact expected from a creative product should not be achieved by the contracting authority but by its customers. For example, in graphic design, a graphic designer becomes a facilitator of the end-user's creative input. [18] A similar link can be observed in the advertising sector. Thus, businesses in the creative industries can have a direct and indirect impact on trends in demand and consumption. The 
link between these sectors and the sustainability trend is also important. For example, ecodesign can have a positive impact on all stages of a product's life cycle. [19] The impact of the creative industry is also significant in the field of innovations and increasing of the economic value of products. [20] Creativity, together with an adequate organizational culture, can even be considered a necessary prerequisite for the creation of innovations. [21]

\section{Methodology and methodology}

This article aims to map the state of the creative industry in individual regions of the Slovak Republic. The companies registered in the Finstat database [22] were subject to review. In terms of the above theoretical background, we have filtered from the database active companies classified according to NACE codes between: Advertising agencies, Specialized design activities, and Architectural activities. To determine the number of companies in individual regions, we used a database of 8326 active companies identified in the above branches of the creative industry. In addition to finding out the structure of creative industries in individual regions, the revenues of these companies were also examined. As the relevant information was available mainly for 2019, companies with information for a different period were excluded from the sample examined in the first step. In the second step, we also excluded from the examined sample companies that had all recorded data for 2019 zero. Thus, a total of 4959 companies were surveyed. We also want to draw attention to certain disadvantages of the database used, which does not provide data on the subjects of the creative industry, which carry out their activities on the basis of trade licenses or as freelancers.

\section{The creative industry in individual regions of the Slovak Republic}

The most represented branch of the creative industry in Slovakia is Reklama, in which 2,5 times more companies operate than the Architecture and Design sector together. In terms of regional distribution, more than $50 \%$ of companies in the creative industries are located in the Bratislava region. On the contrary, the smallest creative companies are located in the Trenčín Region.

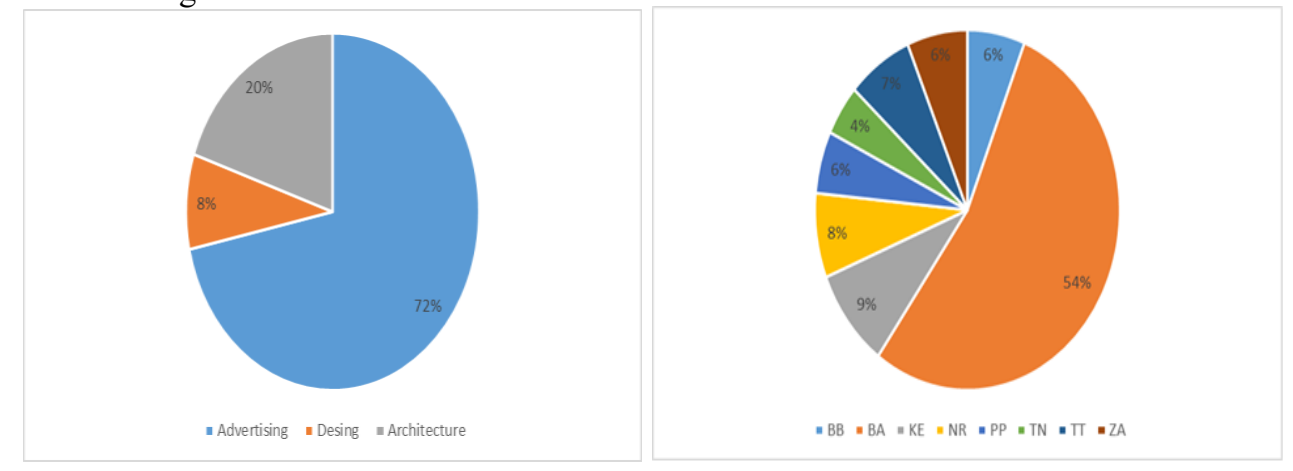

Fig. 1. Representation of the creative industry regions of the SR
Fig. 2. Representation of KP in individual in the SR

Source: own processing 


\subsection{Advertising agencies}

Advertising agencies make up the largest share of the creative industry in each region. The number of companies copies the overall representation of individual regions in the creative industry. Most companies are located in Bratislava and the least in the Trenčín region.

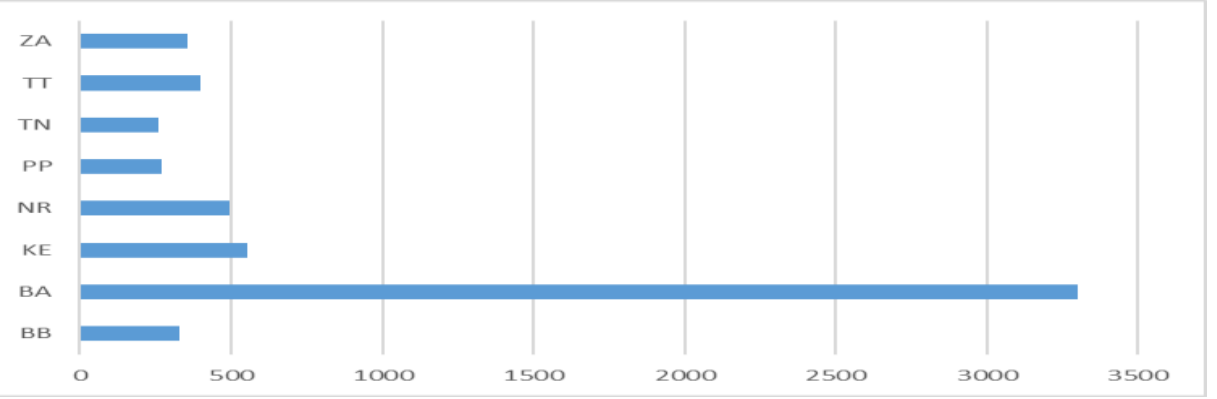

Fig. 3. Representation of Advertising Agencies in individual regions in the SR Source: own processing

The average volume of revenues of one company in the field of advertising is $408219 €$. From the analyzed sample, $42 \%$ of companies achieved revenuesin the range of $10001 €$ to $100000 €$ and others just over $20 \%$ of revenuesin the range of $100001 €$ to $1000000 €$. At the same time, $17 \%$ of companies did not report any sales, which indicates that they did not actively carry out their business activities. It is also interesting to note that $6 \%$ of companies had revenuesof more than 1 mil. $€$.

Table 2. Extent of revenues in individual regions of the SR in 2019

\begin{tabular}{|c|c|c|c|c|c|c|c|c|}
\hline Revenues & BB & BA & $\mathrm{KE}$ & NR & PP & $\mathrm{TN}$ & TT & ZA \\
\hline to $0 €$ & $17 \%$ & $17 \%$ & $18 \%$ & $18 \%$ & $14 \%$ & $19 \%$ & $13 \%$ & $14 \%$ \\
\hline from $1 €$ to $10000 €$ & $19 \%$ & $13 \%$ & $16 \%$ & $9 \%$ & $26 \%$ & $17 \%$ & $16 \%$ & $16 \%$ \\
\hline $\begin{array}{l}\text { from } 10001 € \\
\text { to } 100000 €\end{array}$ & $46 \%$ & $39 \%$ & $44 \%$ & $50 \%$ & $38 \%$ & $44 \%$ & $45 \%$ & $51 \%$ \\
\hline $\begin{array}{l}\text { from } 100001 € \\
\text { to } 1000000 €\end{array}$ & $16 \%$ & $22 \%$ & $19 \%$ & $22 \%$ & $20 \%$ & $19 \%$ & $25 \%$ & $17 \%$ \\
\hline $\begin{array}{l}\text { from } 1000001 € \\
\text { to } 10000000 €\end{array}$ & $2 \%$ & $8 \%$ & $3 \%$ & $1 \%$ & $3 \%$ & $2 \%$ & $1 \%$ & $2 \%$ \\
\hline above $10000000 €$ & $0 \%$ & $1 \%$ & $0 \%$ & $0 \%$ & $0 \%$ & $0 \%$ & $1 \%$ & $0 \%$ \\
\hline $\begin{array}{l}\text { Average revenues per } \\
\text { company in } €\end{array}$ & 127075 & 603161 & 127211 & 91737 & 119323 & 97776 & 167362 & 129527 \\
\hline Median revenues in $€$ & 23875 & 36516 & 23044 & 29871 & 21600 & 19798 & 36871 & 32876 \\
\hline
\end{tabular}

Source: own processing

The highest revenues were achieved in the Bratislava Region, where the average value of revenues per company exceeded 3,5 times the value of average revenues of other regions. However, the highest average value of revenueswas achieved in the Trnava region, where companies achieve revenues mainly in the range from $10001 €$ to $1 \mathrm{mi}$. $€$. In third place, we could include companies in the Žilina region, followed by the Košice and Banská Bystrica regions. Finally, the company achieved the lowest revenues in the Trenčín Region, where most companies did not achieve any revenues. 


\subsection{Architectural activities}

Enterprises carrying out architectural activities are the second largest group of enterprises in the field of creative industries. They have the most significant representation in the Bratislava region, where almost $50 \%$ of them operate. The least of these companies are established in the Trenčín and Nitra regions.

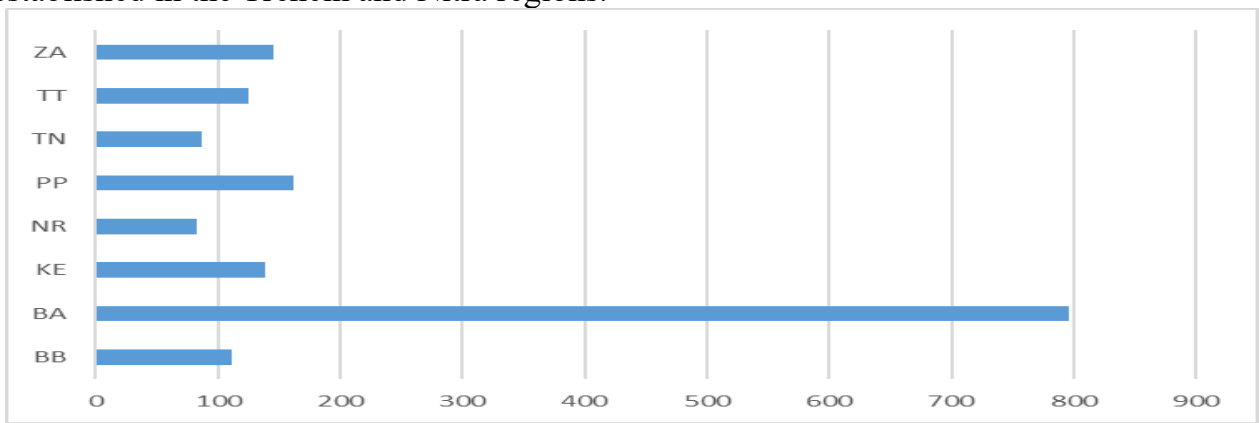

Fig. 4. Representation of companies in the field of Architectural Activities in individual regions in the SR

Source: own processing

The company's average revenues in the field of architecture were $128867 €$, which represents $68 \%$ lower revenues than in advertising. $51 \%$ of companies achieved revenues in the range of $10001 €$ to $100000 €$. In the range of $100001 €$ to $1000000 €, 20 \%$ of companies reported revenues. $13 \%$ of companies did not report any revenues and the same number reached revenues in the range of up to $10000 €$. Revenues over $1000000 €$ reached only $2 \%$ of companies.

Table 3. Extent of revenues in Architectural activities of individual regions of the SR in 2019

\begin{tabular}{|l|c|c|c|c|c|c|c|c|}
\hline Revenues & $\mathrm{BB}$ & $\mathrm{BA}$ & $\mathrm{KE}$ & $\mathrm{NR}$ & $\mathrm{PP}$ & $\mathrm{TN}$ & $\mathrm{TT}$ & $\mathrm{ZA}$ \\
\hline to $0 €$ & $16 \%$ & $15 \%$ & $13 \%$ & $6 \%$ & $13 \%$ & $8 \%$ & $8 \%$ & $8 \%$ \\
\hline from $1 €$ to $10000 €$ & $19 \%$ & $11 \%$ & $18 \%$ & $13 \%$ & $11 \%$ & $16 \%$ & $22 \%$ & $17 \%$ \\
\hline $\begin{array}{l}\text { from } 10001 € \\
\text { to } 100000 €\end{array}$ & $33 \%$ & $49 \%$ & $58 \%$ & $57 \%$ & $52 \%$ & $53 \%$ & $42 \%$ & $63 \%$ \\
\hline $\begin{array}{l}\text { from } 100001 € \\
\text { to } 1000000 €\end{array}$ & $33 \%$ & $21 \%$ & $10 \%$ & $22 \%$ & $22 \%$ & $21 \%$ & $28 \%$ & $10 \%$ \\
\hline $\begin{array}{l}\text { from } 1000001 € \\
\text { to } 10000000 €\end{array}$ & $0 \%$ & $3 \%$ & $0 \%$ & $1 \%$ & $2 \%$ & $2 \%$ & $0 \%$ & $2 \%$ \\
\hline $\begin{array}{l}\text { Average revenues per } \\
\text { company in } €\end{array}$ & 68034 & 154677 & 49437 & 83515 & 111270 & 122643 & 62066 & 99657 \\
\hline Median revenues in $€$ & 38761 & 35479 & 26260 & 38675 & 35122 & 38465 & 31919 & 31653 \\
\hline
\end{tabular}

Source: own processing

The highest revenues were reported in the Bratislava Region, while the highest number of companies achieving revenues in the range of $10001 €$ to $100000 €$, which copies the national parameters. To the second place, we could rank companies in the Trenčín region and then in the Poprad region, while in both these regions, the average revenues exceeded the value of $100001 €$. The smallest revenues in this sector were achieved in the Košice Region, which was caused mainly by the fact that only $10 \%$ of companies achieved revenues above $100000 €$. 


\subsection{Specialized design activities}

As we have already mentioned above, the area of design has the smallest representation in Slovakia within the creative industries. Most companies focused on specialized design activities are traditionally located in Bratislava, while their number exceeds the sum of design companies in other regions. The second place in the number of companies was achieved by the Banská Bystrica region, in which there are five times fewer companies focused on design than in the Bratislava region. The fewest companies can be observed in the Trenčín.

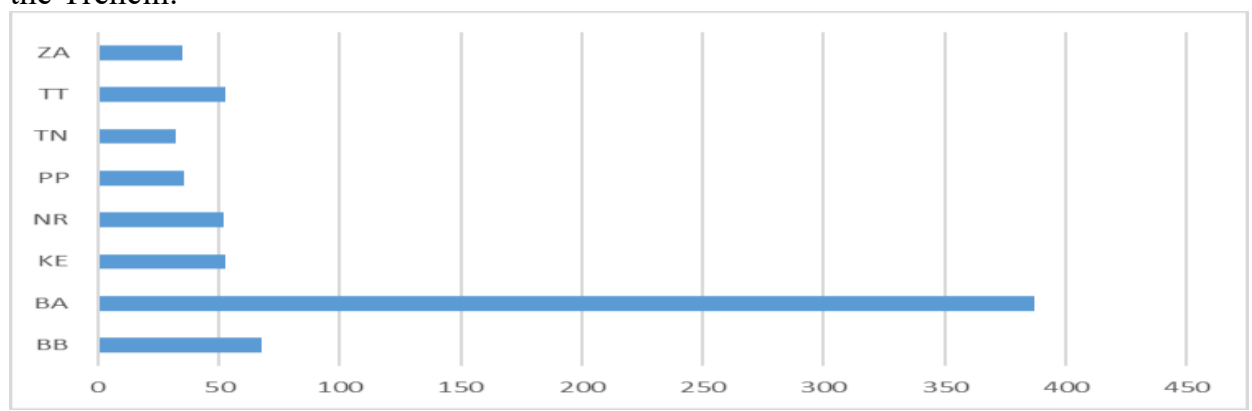

Fig. 5. Representation of companies in the field of specialized design activities in the

Slovak Republic

Source: own processing

Average revenues in design were even lower than in architecture. At the same time, most companies achieved revenues in the range of $10001 €$ to $100000 €$, up to a total of $47 \%$ of companies, and this trend was visible in all regions. Revenues over $€ 1$ million were achieved by only $1 \%$ of companies and over $€ 10$ million. no business. The average revenues were at the level of $84040 €$ per company.

Table 4. Extent of revenues in Design activities of individual regions of the Slovak Republic in 2019

\begin{tabular}{|l|c|c|c|c|c|c|c|c|}
\hline Revenues & BB & BA & KE & NR & PP & TN & TT & ZA \\
\hline to $0 €$ & $17 \%$ & $18 \%$ & $20 \%$ & $16 \%$ & $13 \%$ & $13 \%$ & $18 \%$ & $11 \%$ \\
\hline from $1 €$ to $10000 €$ & $19 \%$ & $13 \%$ & $25 \%$ & $25 \%$ & $25 \%$ & $23 \%$ & $24 \%$ & $31 \%$ \\
\hline $\begin{array}{l}\text { from } 10001 € \\
\text { to } 100000 €\end{array}$ & $51 \%$ & $50 \%$ & $45 \%$ & $43 \%$ & $47 \%$ & $52 \%$ & $40 \%$ & $50 \%$ \\
\hline $\begin{array}{l}\text { from } 100001 € \\
\text { to } 1000000 €\end{array}$ & $10 \%$ & $18 \%$ & $10 \%$ & $15 \%$ & $13 \%$ & $13 \%$ & $18 \%$ & $8 \%$ \\
\hline $\begin{array}{l}\text { from } 1000001 € \\
\text { to } 10000000 €\end{array}$ & $3 \%$ & $2 \%$ & $0 \%$ & $1 \%$ & $3 \%$ & $0 \%$ & $0 \%$ & $0 \%$ \\
\hline $\begin{array}{l}\text { Average revenues per } \\
\text { company in } €\end{array}$ & 65097 & 105468 & 32650 & 69908 & 153222 & 77467 & 48316 & 39447 \\
\hline Median revenues in $€$ & 22162 & 21900 & 14375 & 18455 & 19245 & 36768 & 14240 & 16368 \\
\hline
\end{tabular}

Source: own processing

In terms of regions, the largest average revenues were recorded in the Bratislava region. To its primacy contributed the fact that $20 \%$ of companies achieved revenues of more than $100000 €$ of which $3 \%$ of companies achieved revenues in the range of 1 million $€$ to 3,5 million $€$. The second region in terms of average revenues is the Prešov region. However, its location was mainly due to the fact that there are very few design companies operating in this region, but one achieved revenues of over 2 million $€$. The third highest average revenues were achieved in the Trenčín Region. This result was influenced by the fact, that the highest number of company in this region (52\%) reported revenues in the range of $10001 €$ to $100000 €$. 


\section{Conclusion}

The region with the strongest branch of the creative industry is the Bratislava Region, where there are the highest number of companies involved in the creative industry, and which also at the same time achieve the highest revenues. Within the creative industry in this region, the first place belongs to the Advertising Agencies, which accounted for up to $74 \%$ of creative companies in this region. The fact that several companies in this area achieved revenues of more than 20 mil. $€$ in 2019 also contributed to this matter of fact. In this region, $18 \%$ of creative companies and $9 \%$ of design were dedicated to architecture. The trend in the structure of representation of individual branches of the creative industry in the regions, which can be observed in the Bratislava Region, is also confirmed in all other regions. Their order according to the number of identified creative enterprises is: Košice, Nitra, Trnava, Žilina, Banská Bystrica, Prešov and Trenčín regions. In terms of the share of individual industries in the creative industry within the region, the highest share of the advertising industry can be observed in the Nitra region, the architecture industry in the Prešov region and the design industry in the Banská Bystrica region. Our research confirms the idea of concentrating creative potential in large cities. On the other hand, it can be observed that the creative industry is also alive in regions outside Bratislava.

This paper is an output of the science project VEGA č. 1/0340/19, ,Podnikatel'ský rozmer subjektov kreatívneho priemyslu v kontexte inovácii a inteligentného rastu “, project share is $100 \%$;

\section{References}

1. D. Rybárová, Creative industry as a key creative component of the Slovak economy. Globalization and its Socio-Economic Consequences 2019: Sustainability in the Global-Knowledge Economy. - Zilina : University of Zilina, Faculty of Operation and Economics Transport and Communications, 2020. ISSN 2261-2424, pp. 1-8 online.

2. H. J. R. Z. Lawrence, E. E. Leamer, M. J. Slaughter. Globalization and U.S. Wages: Modifying Classic Theory to Explain Recent Facts. Journal of Economic Perspectives, 26, 119-140 (2019).

3. P. S. Santana, F. F. Silve, Entrepreneurship in the creative industries: A bibliometric study, Brazilian Journal of Management, 12, 125-141 (2019)

4. A. Kovalev, J. Kintler, M. Uhliar. Prognóza reliability legislatívnej kategorizácie podnikov kreatívneho priemyslu v komparácii na dizajn matematických predikčných modelov. Ekonomika a manažment : vedecký časopis Fakulty podnikového manažmentu Ekonomickej univerzity v Bratislave. - Bratislava : Fakulta podnikového manažmentu Ekonomickej univerzity v Bratislave, 16, 9 - 26 (2019)

5. J. Salder, The creative business: enterprise development in the arts-based creative industries. Creative Industries Journal, 14, 63 - 80, (2021)

6. KEA, The economy of culture in Europe [online]. Brusel: KEA, Avaliable at: https://ec.europa.eu/assets/eac/culture/library/studies/cultural-economy_en.pdf (2006)

7. G. Soda, D. Stea, T. Pedersen, Network Structure, Collaborative Context, and Individual Creativity. Journal of Management 45, 1739-1765 (2019)

8. Podrobná definícia odvetví kultúrneho a kreatívneho priemyslu. Avaliable at: https://www.culture.gov.sk/wp-content/uploads/2019/12/Priloha_9_Definicia_ KKP1.pdf (2019)

9. Z. Závadská, J. Závadský, Industry 4.0 and intelligent technologies in the production management innovation. Banská Bystrica : Belianum, 158 p. (2020) 
10. D. Koshy Importance of Design as a Factor of Competitiveness Address at the WIPO International Symposium on Design Santiago, Chile, Avaliable at: https://www.wipo.int/edocs/mdocs/hague/en/ompi_di_san_11/ompi_di_san_11_2.pdf (2011)

11. P. Aghion, N. Bloom, R. Blundell, R. Griffith, P. Howitt, Competition and innovation: an Inverted-U Relationship. Quarterly journal of Economics, 100 (2005)

12. E. Žáková a kol. Kulturní a kreativní průmysly v České republice. Avaliable at: https://www.idu.cz/cs/publikace/726-kulturni-a-kreativni-prumysly-v-ceske-republice (2011)

13. Slovenská komora architektov, Štandardy služieb architekta a postupy stanovenia honoráru. Avaliable at: file://C:/Users/EU/Downloads/tandardy_sluieb_architekta_a_postupy_stanovenia_hon orru.pdf (2021)

14. The Danish Government, Denmark at work plan for growth in the creative industries · design. Avaliable at: https://eng.em.dk/media/10605/07-02-13-summary-vaekstplankreative-erhverv-english.pd (2013)

15. Y. L - Thompkins, A Decade of Online Advertising Research: What We Learned and What We Need to Know. Journal of Advertising, 48, 1-13 (2019)

16. I. Derda, At the intersection of interests: evolving creative processes and new agencymedia dynamics. Creative Industries Journal, 14, 3-22 (2021)

17. S. Yum, The relationship between creative industries and the urban economy in the USA. Creative Industries Journal, 13, 95-116 (2020)

18. S. Taffe,Tensions Facilitating Codesign in Graphic Design: Working with Asthma Educators in Australia. International Journal of Desing, 15 (1) (2021)

19. T. Bhamra, R. J. Hernandez, Thirty years of design for sustainability: an evolution of research, policy and practice. Design Science, 7, 1 - 17, (2021)

20. H. Majdúchová, M. Kmety Barteková, Innovations in the Creative Industry Entities. International Scientific Conference. Globalization and its Socio-Economic Consequences 2019 : Sustainability in the Global-Knowledge Economy. - Zilina : University of Zilina, Faculty of Operation and Economics Transport and Communications, 2020. ISSN 2261-2424, pp. 1-8 online.

21. P. Aghion, U. Akcigit, A. Bergeaud, R. Blundell, D. Hemous, Innovation and Top Income Inequality. The Review of Economic Studies, 86, 1- 45 (2019)

22. Finstat, Online platforma na prácu s dátami o slovenských firmách. Avaliable at: https://www.finstat.sk/ (2021) 